\title{
Teachers' Adoption of Teaching Blog: Analysis of Elementary Schools in Central Taiwan
}

\author{
Yi-Shan Ho, Ching-Ching Cheng, and Kuo Hung Huang
}

\begin{abstract}
The purpose of this study is to investigate elementary school teachers' usage behaviors and attitudes toward teaching blogs. 419 elementary school teachers in Taichung metropolitan area participated in the survey. The results indicated teachers' positive attitude toward teaching blog in terms of perceptions of usefulness and affect toward use. In addition, the results showed significant differences on attitude of teachers with different backgrounds including gender, teaching experiences, and computer training. Furthermore, the obstacles of adoption of teaching blog were investigated. Lack of time was the most common obstacle.
\end{abstract}

Index Terms-ICT in education, social media, teaching blog, technology adoption.

\section{INTRODUCTION}

The rapid advancement of computer network has changed the modern life by accelerating the transfer of human knowledge [1]. Among many Internet services, social network service, such as blog, has been used in establishing relationship and sharing learning experiences. With a 'soapbox' all to themselves, blogs provide their maintainers with the rare opportunity to publish their personal thoughts for the public consumption of such a vast audience can be an uplifting and sometimes cathartic experience [2].

Blog is a means of reaching a wider audience. With many ready and willing to respond to the opinions and commentaries of bloggers, an online network of unknown people of common interest, goal, or experience can interact, share knowledge and information. They strengthen users' concept of behavior and experience, especially in absorbing others' experience [3]-[6].

In addition to serve as an online journal encouraging personal reflection, blogging encourages collaboration through the sharing of links to resources and up to date information, Oravec observes that the blog has many dimensions that are suited to students' 'unique voices', empowering them, and encouraging them to become more critically analytical in their thinking [7].

Godwin-Jones indicates that through blogging, people are able to document their reflections about things relevant to their daily life experiences, providing new opportunities and

Manuscript received October 29, 2012; revised January 15, 2013.

Y. S. Ho is with the Hui Wen Elementary School, Taichung 408, Taiwan (e-mail: g1000539@pu.edu.tw).

C. C. Cheng is with the Graduate Institute of Education, Providence University, Taichung 43301, Taiwan (e-mail: cccheng@ pu.edu.tw).

K. H. Huang is with the Department of E-learning Design and Management, National Chiayi University, Chiayi 621, Taiwan (e-mail: kuohung@mail.ncyu.edu.tw). incentives for personal writing [8], [9].

Many prior studies confirm that blog is an effective educational technology to promote learning by providing learning resources or facilitating collaborative activities [10]-[14]. In this study, the authors investigated teachers' attitude toward teaching blog and identified the major obstacles of adoption.

\section{RESEARCH METHODS}

Survey was used to investigate teachers' intention and behaviors. Questionnaires were mailed to elementary teachers in central Taiwan.

\section{A. Subjects}

The subjects are the elementary teachers in Taichung city, which owned schools of different sizes. There were 234 elementary schools and 4344 teachers in 2011. To avoid bias in scale of schools, stratified sampling was used. As shown in Table I, 450 questionnaires were mailed to elementary teachers in central Taiwan. In the end, 419 valid questionnaires were used as the data for analysis. Among them, $72.6 \%$ were female teachers.

TABLE I: SAMPLING OF THE SURVEYED TEACHERS

\begin{tabular}{cccc}
\hline \hline $\begin{array}{c}\text { School } \\
\text { Size }\end{array}$ & $\begin{array}{c}\text { Number of } \\
\text { all teachers }\end{array}$ & $\begin{array}{c}\text { Percentage } \\
\text { of all } \\
\text { teachers }\end{array}$ & $\begin{array}{c}\text { Number of } \\
\text { sampled } \\
\text { teachers }\end{array}$ \\
\hline $\begin{array}{c}\text { Small size } \\
(<=36 \text { classes })\end{array}$ & 1481 & $34 \%$ & 153 \\
Medium size & 1369 & $31 \%$ & 140 \\
$(37$ to 60 classes $)$ & & & 157 \\
\hline Large size & & & \\
$(>=61$ classes $)$ & 1494 & $35 \%$ & 450 \\
\hline total & 4344 & $100 \%$ & \\
\hline \hline
\end{tabular}

\section{B. Instruments}

The questionnaire was designed to collect information on teachers' background, attitude toward using teaching blogs, actual usage of teaching blogs, and feedback from students and their parents.

The background session consisted of items on teachers' gender, age, years of teaching, education, and computer skills.

The attitude session consisted of items on knowledge, self-efficacy, affect toward use, and perceived usefulness.

The actual usage session consisted of items on the names of teaching blogs used, duration of usage per day, articles 
posted per day, and posted content.

The feedback session consisted of items on skills on blogging, teachers' professional reflection, communications with students and parents, students' reaction and use behavior, and students' learning achievement.

\section{Data Analysis}

ANOVA and t-test were used to verify the differences. Person correlation analysis was used to test the connection between the usage of teaching blogs and behavior changed.

\section{RESULTS: USAGE}

As in Table II to Table V, the descriptive statistics showed teachers' use behaviors of teaching blogs. The most popular blog platforms are owned by school and Uschool (see Table II). These two platforms are specific designed for educational purposes, whose functions meet the teachers' needs.

TABLE II: BLOG PLATFORMS USED BY TEACHERS

\begin{tabular}{lcc}
\hline \hline Platforms used & $\mathrm{n}$ & $\%$ \\
\hline Owned by School & 324 & 79.0 \\
Kimo Yahoo & 56 & 13.7 \\
Wretch & 71 & 17.3 \\
Sino & 7 & 1.7 \\
Windows Live Messenger & 35 & 8.5 \\
Kimo Yam & 26 & 6.3 \\
Owned by self & 13 & 3.5 \\
Uschool & 126 & 30.7 \\
Roodo & 5 & 1.2 \\
Xuite & 29 & 7.1 \\
Others & 4 & 1.0 \\
\hline \hline
\end{tabular}

TABLE III: NuMBER OF ARTICLES POSTED PER WEEK

\begin{tabular}{ccc}
\hline \hline Number of articles & $\mathrm{n}$ & $\%$ \\
\hline Less than 1 & 318 & 75.9 \\
1 to 3 & 85 & 20.3 \\
4 to 6 & 16 & 3.8 \\
\hline \hline
\end{tabular}

TABLE IV: TIME SPENT ON MAINTAINING BLOG PER DAY

\begin{tabular}{llc}
\hline \hline Time spent & $\mathrm{n}$ & $\%$ \\
\hline Less than 30 minutes & 370 & 88.3 \\
Between 0.5 to 1 hour & 40 & 9.5 \\
Between 1 to 1.5 hour & 6 & 1.4 \\
Between 1.5 to 2 hours & 1 & .2 \\
More than 2 hours & 2 & .5 \\
\hline \hline
\end{tabular}

Most teachers spent less than 30 minutes in browsing or maintaining blog content. The reason is they are busy with class activities (see Table III to Table V).

Most teachers used blogs to make announcements and display photos and students' works (see Table VI).
TABLE V: TIME SPENT ON BROWSING BLOG

\begin{tabular}{|c|c|c|}
\hline Time spent & $\mathrm{n}$ & $\%$ \\
\hline Less than 30 minutes & 358 & 85.4 \\
\hline Between 0.5 to 1 hour & 46 & 11.0 \\
\hline Between 1 to 1.5 hour & 11 & 2.6 \\
\hline Between 1.5 to 2 hours & 2 & .5 \\
\hline More than 2 hours & 2 & .5 \\
\hline \multicolumn{3}{|c|}{ TABLE VI: FUNCTIONS OF THE BLOGS THAT TEACHERS USED } \\
\hline Functions on the blogs used & $\mathrm{n}$ & $\%$ \\
\hline Display students' works & 320 & 76.6 \\
\hline Class affairs announcements & 319 & 76.3 \\
\hline Communications with parents & 170 & 40.7 \\
\hline Display photos of activities & 340 & 81.3 \\
\hline Teachers' reflection notes & 96 & 23.0 \\
\hline Supplements to teaching & 142 & 34.0 \\
\hline Communications with students & 141 & 33.7 \\
\hline Others & 17 & 4.1 \\
\hline
\end{tabular}

\section{RESULTS: DIFFERENCES}

Statistical methods such as t-Test and ANOVA were used to test the significance of differences between the usage behavior and background.

The SI unit for magnetic field strength $H$ is $\mathrm{A} / \mathrm{m}$. However, if you wish to use units of $\mathrm{T}$, either refer to magnetic flux density $B$ or magnetic field strength symbolized as $\mu_{0} H$. Use the center dot to separate compound units, e.g., "A· $\mathrm{m}^{2}$."

\section{A. Gender}

TABLE VII: GENDER DIFFERENCE IN ATTITUDE TOWARD TEACHING BLOG

\begin{tabular}{lccccc} 
& gender & $\mathrm{n}$ & $\mathrm{M}$ & $\mathrm{SD}$ & $\mathrm{t}$ \\
\hline Knowledge & $\mathrm{M}$ & 115 & 3.26 & .50 & $2.85^{* * *}$ \\
& $\mathrm{~F}$ & 304 & 3.11 & .45 & \\
\hline Self-efficacy & $\mathrm{M}$ & 115 & 3.23 & .52 & 1.5 \\
& $\mathrm{~F}$ & 304 & 3.15 & .44 & \\
Affect & $\mathrm{M}$ & 115 & 2.93 & .49 & 1.03 \\
Toward Use & $\mathrm{F}$ & 304 & 2.87 & .51 & \\
\hline Perceived & $\mathrm{M}$ & 115 & 2.94 & .51 & 1.57 \\
Usefulness & $\mathrm{F}$ & 304 & 2.85 & .52 & \\
\hline \hline
\end{tabular}

$* * \mathrm{p}<.01$

In terms of gender, male teachers tend to know about the history and functionalities of teaching blog. Besides, no significant differences exist in attitude between male and female teachers (see Table VII).

\section{B. School Size}

In terms of school size, teachers at large schools tend to express positive attitude toward teaching blog (see Table VIII). 
TABLE VIII: SCHOOL SIZE DIFFERENCES IN ATTITUDE TOWARD TEACHING BLOG

\begin{tabular}{llccccc}
\hline \hline & School Size & $\mathrm{n}$ & $\mathrm{M}$ & $\mathrm{SD}$ & $\mathrm{F}$ & Comp. \\
\hline \multirow{2}{*}{ Knowledge } & Small & 134 & 3.15 & .47 & & \\
& Medium & 136 & 3.10 & .44 & 1.81 & \\
& Large & 149 & 3.21 & .49 & & \\
\hline \multirow{2}{*}{ Self-efficacy } & Small & 134 & 3.15 & .47 & & \\
& Medium & 136 & 3.11 & .41 & $3.40^{*}$ & $3>2$ \\
& Large & 149 & 3.25 & .48 & & \\
Affect & Small & 134 & 2.78 & .51 & & \\
Toward & Medium & 136 & 2.84 & .42 & $10.77^{*}$ & $3>1$ \\
Use & Large & 149 & 3.03 & .53 & & $3>2$ \\
\hline Perceived & Small & 134 & 2.80 & .54 & & \\
Usefulness & Medium & 136 & 2.80 & .48 & $8.96^{* *}$ & $3>1$ \\
& Large & 149 & 3.02 & .53 & & $3>2$ \\
\hline \hline
\end{tabular}

$* \mathrm{p}<.05, * * \mathrm{p}<.01$

\section{Educational Background}

In terms of education background, no significant differences exist in attitude between teachers with different educational degrees (see Table IX).

TABLE IX: EDUCATION LEVEL DIFFERENCES IN ATTITUDE TOWARD TEACHING BLOG

\begin{tabular}{|c|c|c|c|c|c|}
\hline & Degree & $\mathrm{n}$ & M & SD & $\mathrm{F}$ \\
\hline \multirow[t]{3}{*}{ Knowledge } & Associate & 0 & 0 & 0 & \multirow{3}{*}{0.96} \\
\hline & Bachelor & 187 & 3.13 & .47 & \\
\hline & Mater & 232 & 3.17 & .47 & \\
\hline Perceived & Associate & 0 & 0 & 0 & \multirow{3}{*}{2.46} \\
\hline Behavior & Bachelor & 187 & 3.13 & .44 & \\
\hline Self-efficacy & Mater & 232 & 3.20 & .47 & \\
\hline Affect & Associate & 0 & 0 & 0 & \multirow{3}{*}{0.18} \\
\hline Toward & Bachelor & 187 & 2.88 & .52 & \\
\hline Use & Mater & 232 & 2.90 & .49 & \\
\hline Perceived & Associate & 0 & 0 & 0 & \multirow{3}{*}{0.32} \\
\hline \multirow[t]{2}{*}{ Usefulness } & Bachelor & 187 & 2.88 & .51 & \\
\hline & Mater & 232 & 2.87 & .53 & \\
\hline
\end{tabular}

\section{Computer Training}

In terms of computer background, significant difference exists in knowledge and self-efficacy between teachers majoring in computer or non-computer (see Table X).

\section{E. Teaching Experience}

In terms of computer background, no significant differences exist in attitude between teachers majoring in computer or non-computer (see Table XI).

TABLE X: COMPUTER TRAINING DIFFERENCES IN ATTITUDE TOWARD TEACHING BLOG

\begin{tabular}{llcccc}
\hline \hline & College major & $\mathrm{n}$ & $\mathrm{M}$ & $\mathrm{SD}$ & $\mathrm{F}$ \\
\hline Knowledge & Non-Computer & 378 & 3.13 & .46 & \\
& Computer & 41 & 3.38 & .46 & $11.28^{* *}$ \\
\hline Self- & Non-Computer & 378 & 3.15 & .46 & \\
efficacy & Computer & 41 & 3.35 & .42 & $6.62^{*}$ \\
\hline $\begin{array}{l}\text { Affect } \\
\text { Toward }\end{array}$ & Non-computer & 378 & 2.88 & .51 & \\
Use & Computer & 41 & 2.94 & .49 & 0.52 \\
\hline Perceived & Non-computer & 378 & 2.87 & .51 & 0.78 \\
Usefulness & Computer & 41 & 2.85 & .61 & \\
\hline \hline
\end{tabular}

$* \mathrm{p}<.05 * * \mathrm{p}<.01$

TABLE XI: TEACHING EXPERIENCE DIFFERENCES IN ATTITUDE TOWARD TEACHING BLOG

\begin{tabular}{|c|c|c|c|c|c|}
\hline & Years of teaching & $\mathrm{n}$ & M & $\mathrm{SD}$ & $\mathrm{F}$ \\
\hline \multirow[t]{5}{*}{ Knowledge } & Under 5 & 29 & 3.16 & .42 & \multirow{5}{*}{0.84} \\
\hline & $6 \sim 10$ & 162 & 3.18 & .47 & \\
\hline & $11 \sim 15$ & 123 & 3.13 & .48 & \\
\hline & $16 \sim 20$ & 42 & 3.05 & .48 & \\
\hline & Above 21 & 63 & 3.19 & .45 & \\
\hline \multirow[t]{5}{*}{ Self-efficacy } & Under 5 & 29 & 3.02 & .28 & \multirow{5}{*}{1.02} \\
\hline & $6 \sim 10$ & 162 & 3.19 & .50 & \\
\hline & $11 \sim 15$ & 123 & 3.16 & .45 & \\
\hline & $16 \sim 20$ & 42 & 3.18 & .43 & \\
\hline & Above 21 & 63 & 3.21 & .45 & \\
\hline \multirow{5}{*}{$\begin{array}{l}\text { Affect } \\
\text { Toward } \\
\text { Use }\end{array}$} & Under 5 & 29 & 2.86 & .44 & \multirow{5}{*}{0.35} \\
\hline & $6 \sim 10$ & 162 & 2.88 & .56 & \\
\hline & $11 \sim 15$ & 123 & 2.89 & .45 & \\
\hline & $16 \sim 20$ & 42 & 2.85 & .52 & \\
\hline & Above 21 & 63 & 2.95 & .48 & \\
\hline \multirow{5}{*}{$\begin{array}{l}\text { Perceived } \\
\text { Usefulness }\end{array}$} & Under 5 & 29 & 2.91 & .39 & \multirow{5}{*}{0.44} \\
\hline & $6 \sim 10$ & 162 & 2.84 & .55 & \\
\hline & $11 \sim 15$ & 123 & 2.91 & .49 & \\
\hline & $16 \sim 20$ & 42 & 2.86 & .58 & \\
\hline & Above 21 & 63 & 2.90 & .53 & \\
\hline
\end{tabular}

\section{RESULTS: CORRELATION}

Pearson correlation method was used to test the correlation between teachers' attitude and feedback. As in Table XII, affect toward use is highly related to teachers' perceptions on the rewarding results from using blogs. The next is perceived usefulness. The result showed that a useful and delightful design of blog platform would attract teachers to use and then created positive impacts on their teaching tasks.

The least relevant pair was knowledge and teachers' reflection. It indicated that using blog, instead of knowing the functions, was able to facilitate teachers' reflection. 
TABLE XII: CORRELATION BETWEEN TEACHERS’ ATTITUDE AND FEEDBACK

\begin{tabular}{|c|c|c|c|c|}
\hline & $\begin{array}{c}\text { Blogging } \\
\text { skills }\end{array}$ & $\begin{array}{c}\text { Class } \\
\text { management }\end{array}$ & $\begin{array}{l}\text { Communi- } \\
\text { cation }\end{array}$ & $\begin{array}{l}\text { Teachers' } \\
\text { reflection }\end{array}$ \\
\hline knowledge & $.38^{* *}$ & $.30 * *$ & $.21 * *$ & $.11 *$ \\
\hline self-efficacy & $.46^{* * *}$ & $.40 * *$ & $.34 * *$ & $.19 * *$ \\
\hline Affect toward & $.58 * *$ & $.69 * *$ & $.60^{* * *}$ & $.41 * *$ \\
\hline $\begin{array}{c}\text { use } \\
\text { perceived } \\
\text { usefulness }\end{array}$ & $.57 * *$ & $.57 * *$ & $.54 * *$ & $.38 * *$ \\
\hline
\end{tabular}

$* \mathrm{p}<.05, * * \mathrm{p}<.01$

\section{RESULTS: OBSTACLES}

Among the obstacles of using teaching blog, lack of time is the top reason. In addition, insufficient facility is the second reason (see Table XIII).

Authors of rejected papers may revise and resubmit them to the journal again.

TABLE XIII: PERCENTAGE OF PERCEIVED OBSTACLES

\begin{tabular}{lcc}
\hline \hline \multicolumn{1}{c}{ obstacle } & number & percentage \\
\hline 1. User-unfriendly interface design & 136 & 32.9 \\
2. Functionalities not fit for job & 71 & 16.9 \\
3. Little feedback & 80 & 19.1 \\
4. Lack of time due to heavy workload & 353 & 84.2 \\
5. Insufficient computer abilities & 100 & 23.9 \\
6. Difficulty in writing & 142 & 33.9 \\
7. Slow upload speed or insufficient storage & 197 & 47.0 \\
8. Pressures from job evaluation & 126 & 30.1 \\
9. No support for solving problems & 57 & 13.6 \\
10.Students lack of computer skills & 96 & 22.9 \\
11.Students do not access to computers & 150 & 35.8 \\
12.Students are interested & & 20.5 \\
\hline \hline
\end{tabular}

\section{DISCUSSION}

Blogs allow people to exchange information without space and time constraints, to broaden their knowledge, and to meet personal needs and interests at the same time. With this media for educational purpose, teachers are able to deliver and share information, as well as communicate with students and parents.

The research findings indicated the positive attitude toward teaching blog. Although teachers are too busy to post many articles and pictures, they still consider technology a good tool to facilitate communication between teachers and students/parents. Nevertheless, more research should be conducted before encouraging schools or teachers to integrate teaching blog in schools.

\section{REFERENCES}

[1] Y. L. Lee, S. B. Chiang, and C. J. Wu, "A study on perceived interactivity and perceived value of facebook and their connection to loyalty," Journal of Design Research, vol. 4, pp. 50-66, 2010.

[2] J. Jacobs, "Communication over exposure: The rise of blogs as a product of cybervoyeurism," in C. Hatcher, J. Jacobs, and T. Flew, Eds., Australian and New Zealand Communication Association Conference Proceedings, Brisbane, 2003.

[3] I. Kang, C. J. Bonk, and M. C. Kim, "A case study of blog-b ased learning in Korea: Technology becomes pedagogy," The Internet and Higher Education, vol. 14, pp. 227-235, 2011.

[4] A. Blanchard and T. Horan, "Virtual communities and social capital," Social Science computer Review, vol. 16, no. 5, pp. 293-307, 1998.

[5] S. Puntambekar, "Analyzing collaborative interactions: divergence, shared understanding and construction of knowledge," Computers and Education, no. 47, pp. 332-351, 2006.

[6] J. M. Carroll and J. R. Olson "Mental models in human-computer interaction," in M. Helander, Ed., Handbook of human-computer interaction, Amsterdam: Elsevier, 1998.

[7] J. Oravec, "Bookmarking the world: Weblog applications in education," Journal of Adolescent and Adult Literacy, vol. 45, no. 7, pp. 616-621, 2002.

[8] B. Godwin-Jones, "Emerging technologies: Blogs and wikis: Environments for on-line collaboration," Language Learning \& Technology, vol. 7, no. 2, pp. 12-16, 2003.

[9] B. Godwin-Jones, "Emerging technologies: Web-writing 2.0: Enabling, documenting, and assessing writing online," Language Learning \& Technology, vol. 12, no. 2, pp. 7-13, 2008.

[10] B. Shneiderman, Designing the user interface: Strategies for effective human-computer-interaction, Reading, MA: Addison Wesley Longman, 2002.

[11] M. E. Flatley, "Blogging for enhanced teaching and learning," Business Communication Quarterly, vol. 68, no. 1, pp. 77-80, 2005.

[12] E. Z. Liu and H. T. Lin, "Blogging your learning reflections, "WSEAS Transactions on Computers, vol. 6, no. 4, pp. 692-698, 2007.

[13] K. C. Seal and Z. H. Przasnyski, "Using the world wide web for teaching improvement," Computers \&Education, no. 36, pp. 33-40, 2001.

[14] L. Wells, "Blog it: an innovative way to improve literacy," Reading Today, vol. 24, no. 1, pp. 40, 2006.
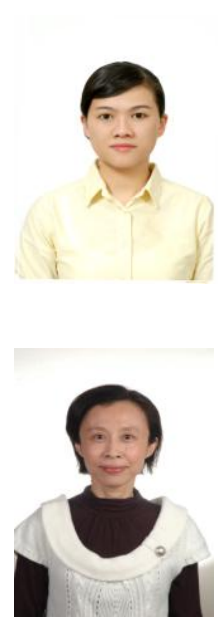

Yi-Shan Ho was born in 1978, in Taiwan. She received her Bachelor degree in early childhood education from National Taitung University in 2000. In 2013, she received her master degree in education from Providence University, Taiwan. Currently, she is teaching at Hui-wen elementary school. Her research interests include early childhood education and elementary education.
Prof. Cheng has served as the associate Dean of academics to improve university teaching quality. In addition, she is frequently consulted for making policy in early childhood education.

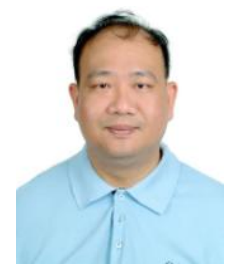

Ching-Ching Cheng was born in 1968, in Taiwan. She received her Master and Doctor degree in home economics education from National Taiwan Normal University in 1993 and 2002 respectively. Currently, she is associate professor at the Graduate Institute of Education at Providence University, Taiwan. Her research interests include early childhood education, teacher education, and e-learning.

Kuo Hung Huang was born in 1965, in Taiwan. He received his Master degree of computer science from North Carolina State University in 1992. In 2000, he received his $\mathrm{PhD}$ of science education from National Changhua University of Education in Taiwan. Currently, he is professor and chairman in the Department of E-learning Design and at National Chiayi University, Taiwan. For years, he has been participating in the Taiwan e-Learning and Digital Archives Program for promoting the digital library resources in schools. In addition, he distributes animations of the digitized resources to the general public for further disseminating knowledge and culture. Since 2009, he has being conducting projects adopting GIS to integrate science learning and humanity learning. 